\title{
An Investigation into the Use of Ducktail at Transom Stern to Reduce Total Ship Resistance
}

\author{
Fiqih Dwi Kurniawati ${ }^{1}$ and I Ketut Aria Pria Utama ${ }^{1}$
}

\begin{abstract}
In this study it is aimed to investigate the application of ducktail at transom stern to reduce total resistance using Computational Fluid Dynamics (CFD). Ducktail is additional retrofit device to reduce effect of wetted transom causes wave and wake which cannot fully generate far away therefore absorbs energy. The method about saving energy possibilities was determined. The RANSE code CFX fitted with shear stress transport (SST) turbulence is used to carry out the simulation. Grid generator ICEM CFD is used to build hybrid grids for RANS code solvers. The result indicate ducktail reduce resistance significantly based on Froude numbers. The wave and wake fully transmitted into the far field. Ducktail becomes alternative appendages to increase energy efficiency.
\end{abstract}

Keywords-Ducktail, Ranse solver, Computational Fluid Dynamics, Froude numbers, transom.

\section{INTRODUCTION}

The increase of global warming issue in the last two decades caused by pollution and greenhouse gasses (GHG) has motivated ship designers to improve ship design become more economical and environmental friendly. At present modern ship passenger consume 50.000 tons fuel oils annually [1]. In 2009 International Maritime Organization (IMO) has given extensive consideration to control GHG emissions from ships. In 2013 new mandatory regulation to aim of reducing CO2 emission, known as Energy Efficiency Design Index (EEDI) has launched and apply to all new ships. This index assesses the ratio of emissions over the benefit to the society [2]. The new idea of the issue for the reduction in power demand by that so-called Energy Saving Devices (ESDs). ESD is the application that aims to increase efficiency in ship power and give alternative energy. Basically, ESDs is retrofit design, which means adding devices can be applied on the new ships or existing ships [3]. In this work analyses the example the one of ESDs devices that aimed to reduce total resistance. Ferry design basically have transom shape at stern. Transom is simple design to reduce process assembly effort in ship production otherwise has negative effect to cause circulation zone at wetted transom [4].

For ferry vessel at Froude Numbers (Fr) of 0,2-0,3 or higher it is nowadays recommended to increase length of aft body without increasing overall length of ship, later known as ducktail. A ducktail is basically a lengthening of the aft ship. The basic idea is to lengthen the effective waterline and make the wetted transom smaller. This has a positive effect to reduce the ship resistance. The adding a ducktail significantly reduces power about 4-7\% [5].

${ }^{1}$ Fiqih Dwi Kurniawati and I Ketut Aria Pria Utama are with Department of Naval Architecture and Shipbuilding, Institut Teknologi
Wetted transom has negative effect to increase resistance, causes waves and wave breaking and spray at behind transom which are not fully transmitted to the far field [6]. Since the wake cannot be transmitted far away from aft body, thus eddies current cannot be generated therefore absorb energy. A ducktail can be fitted like a fin longwise behind wetted transom. This work analyses the effect of adding ducktail using Computational Fluid Dynamics (CFD) method. CFD predicts and visualizes fluid phenomena that happen during simulation, that cannot be catched at experimental test and it has become preliminary data to analyze hydrodynamics aspect before real experimental test. Today, Reynold average Navier-Stokes (RANS) solvers for incompressible flow developed by CFD code have included Eulerian-eulerian multiphase, free surface around the hull with shear stress transport (SST) based k-w turbulence model is used to carry out the simulation. Grid Generator was used to build hybrid grids for RANS code solver.

\section{METHOD}

\section{A. Description of Model}

This study explored ferry ship with conventional transom stern which is modified with adding ducktail fitted on transom stern. The size of ducktail is user defined. In this work using length 3 and 6 meter. The model using 3 dimensional (3D) drawing and particular dimension of model using scale 1:25 of initial ferry ship. The ship travelled at Froude numbers 0.20 which equals to $18 \mathrm{knot}$ at full scale ship and $1.85 \mathrm{~m} / \mathrm{s}$ at model scale. Table 1 shows the particular dimension of conventional ferry model while Figure 1 display the model of initial ferry and model using ducktail with different length. The ducktail fitted a longwise behind transom and is not fully in underwater but slightly on draft maximum.

$$
\frac{\partial \rho}{\partial t}+\frac{\partial}{\partial x_{j}}\left(\rho U_{j}\right)=0
$$

$\frac{\partial \rho U_{j}}{\partial t}+\frac{\partial}{\partial x_{j}}\left(\rho U_{i} U_{j}\right)=-\frac{\partial p}{\partial x_{i}}+\frac{\partial}{\partial x_{j}}\left(\tau_{i j}-\rho \bar{U}_{\imath} \bar{U}_{J}\right)+S_{M}$

Where $\tau$ the molecular tensor (including both normal and shear component of the stress). In CFD code turbulence model has important role to predict effect of turbulence.

\section{B. Mathematical model}

Mathematical description of free surface flow in CFD code is based on the homogenous multiphase EulerianEulerian fluid approach. Both fluids (water and air) in this approach share the same velocity and other relevant fields 
such as temperature, turbulence, etc., which is separated by a distinct resolvable interface. The local equations governing the motion of unsteady, viscous and incompressible fluid (either liquid or gas) namely NavierStokes, which is derived from the basic principles of conservation of mass, momentum, and energy it is necessary to consider a finite volume, called a control volume. In general, turbulence models seek to modify the original unsteady Navier-Stokes equations by the introduction of averaged and fluctuating quantities to produce the Reynolds Averaged Navier-Stokes (RANS) equations. These equations represent the mean flow quantities only, while modeling turbulence effects without a need for the resolution of the turbulent fluctuations. All scales of the turbulence field are being modeled. Turbulence models based on the RANS equations are known as Statistical Turbulence Models due to the statistical averaging procedure employed to obtain the equations. The RANS averaged equation given below.

Where $\tau$ the molecular tensor (including both normal and shear component of the stress). In CFD code turbulence model has important role to predict effect of turbulence in simulation. Turbulence model using SST based k- $\omega$ it accounts for the transport of the turbulent shear stress and gives highly accurate predictions of the onset and the amount of flow separation [7]. This model use two equation model which has turbulent kinetic energy and combine $\mathrm{k}-\varepsilon$ model to predict turbulent far field outside boundary layer and $\mathrm{k}-\omega$ to predict turbulent at inner boundary layer. The SST based k- $\omega$ turbulent model was used in CFD code formulated by

$$
\begin{gathered}
\frac{\partial(\rho k)}{\partial_{t}}+\frac{\partial}{\partial_{x_{i}}}\left(\rho k u_{i}\right)=\frac{\partial}{\partial x_{j}}\left(\Gamma_{k} \frac{\partial k}{\partial x_{j}}\right)+G_{k}-Y_{k} \\
\frac{\partial(\rho \omega)}{\partial_{t}}+\frac{\partial}{\partial_{x_{i}}}\left(\rho \omega u_{i}\right)=\frac{\partial}{\partial x_{j}}\left(\Gamma_{\omega} \frac{\partial \omega}{\partial x_{j}}\right)+G_{\omega}-Y_{\omega}+D_{\omega}
\end{gathered}
$$

Where $\Gamma \mathrm{k}$ and $\Gamma \omega, \mathrm{Gk}$ and $\mathrm{G} \omega$, and $\mathrm{Yk}$ and $\mathrm{Y \omega}$ respectively represent the effective diffusivity for $\mathrm{k}$ and $\omega$, generation of turbulence kinetic energy and $\omega$ due to mean velocity gradients, and dissipation of $\mathrm{k}$ and $\omega$ due to turbulence respectively. Meanwhile D $\omega$ represents the cross-diffusion term.

\section{Computational Grid}

Computational grid using grid generator code was used to generate hybrid grid or mesh. Hybrid mesh combine unstructured tetrahedral to construct volume and model and inflation layer to construct boundary layer around the model. The wall distance of the first grid point of the model surface was maintained for each case, $y+\approx 60$ which is within log law [8]. The behavior of the flow near the wall is a complicated phenomenon and to distinguish the different region near the wallthe concept of wall has been formulated. Thus the wall distance is dimensionless quantity and is distance from the wall measured in term of viscous length. Computation domain has to be restricted by boundaries of one type or another depending on problem setup and on functions to be performed by these boundaries in the solution. Figure. 2 display the computational domain and the size that used in simulation. The computational domain of the model which is extended to $1.5 \mathrm{~L}$ forward on ship direction, $3 \mathrm{~L}$ backward at behind ship, $1.75 \mathrm{~L}$ aside right and left and $1.5 \mathrm{~L}$ downward under the keel of the model. For the air layered was extended to $0.5 \mathrm{~L}$ above the still water surface. To obtain the finer mesh and accurate in running time simulation, thus mesh conducted with smoothing process to obtain mesh which have better quality. With refinement mesh can improve quality to achieve accurate of calculation and captured smooth contour around the ship model. To increase efficiency in running process the mesh has been generated with scale factor which means the mesh has gradual size for volume mesh in order to reduce total elements. The mesh was refined in the free surface region in order to get a sharp free surface. Furthermore, for predicting accurate values for total force the mesh elements were refined on and near the ship hull surface in order to calculate accurate pressure forces acting on the hull form at range Froude numbers [9]. Total elements of three type of model are about 1.5 million elements. Figure 3 shows the hybrid mesh that used in simulation. The mesh included unstructured tetrahedral and inflation layer around the ship. The mesh independence is carried to determine optimum mesh. The coarse mesh will not capture all flow features and a finer mesh will give solution a little higher accuracy than the coarse mesh. Table 2 showed the various of mesh that have been simulated. The mesh resolution has been indicated that the changed of different total element of mesh 3 and 4 is under $2 \%$ which mean the mesh 3 is good enough to get independency. Mesh 3 is used to run simulation.

\section{Computational method and boundary condition}

The no-slip boundary condition is imposed on the hull surface of the model that is the fluid particles on the body move with body velocity. Inlet is specified main velocity distribute that fluid entered domain with intensity of turbulence is set at $5 \%$. The static pressure at the outlet boundary was defined as a function of water volume fraction. Furthermore, the initial location of the free surface was imposed by defining the volume fraction functions of water and air at the inlet and outlet boundaries. The flow was considered steady flow in CFD simulation. Computation was run on an i7 processor, 7 core hyper threading, $3.6 \mathrm{GHz}$ and $32 \mathrm{~GB}$ RAM with the effect of free surface and surface without wave and current. The water region width was set to three and half of ship lengths as to eliminate the wall effect and no-slip boundary condition was imposed on the hull surface. The static pressure and initial location of the free surface were accordingly defined by the function of water volume fraction at the outlet boundary and volume fraction of water and air at both inlet and outlet boundaries. The automatic scalable wall function was used with turbulence model while the reference pressure was set to the atmospheric pressure. The flow was considered steady in CFD code calculations with utilization of finite volume method and high resolution numerical scheme for discretization process and advection terms respectively. 

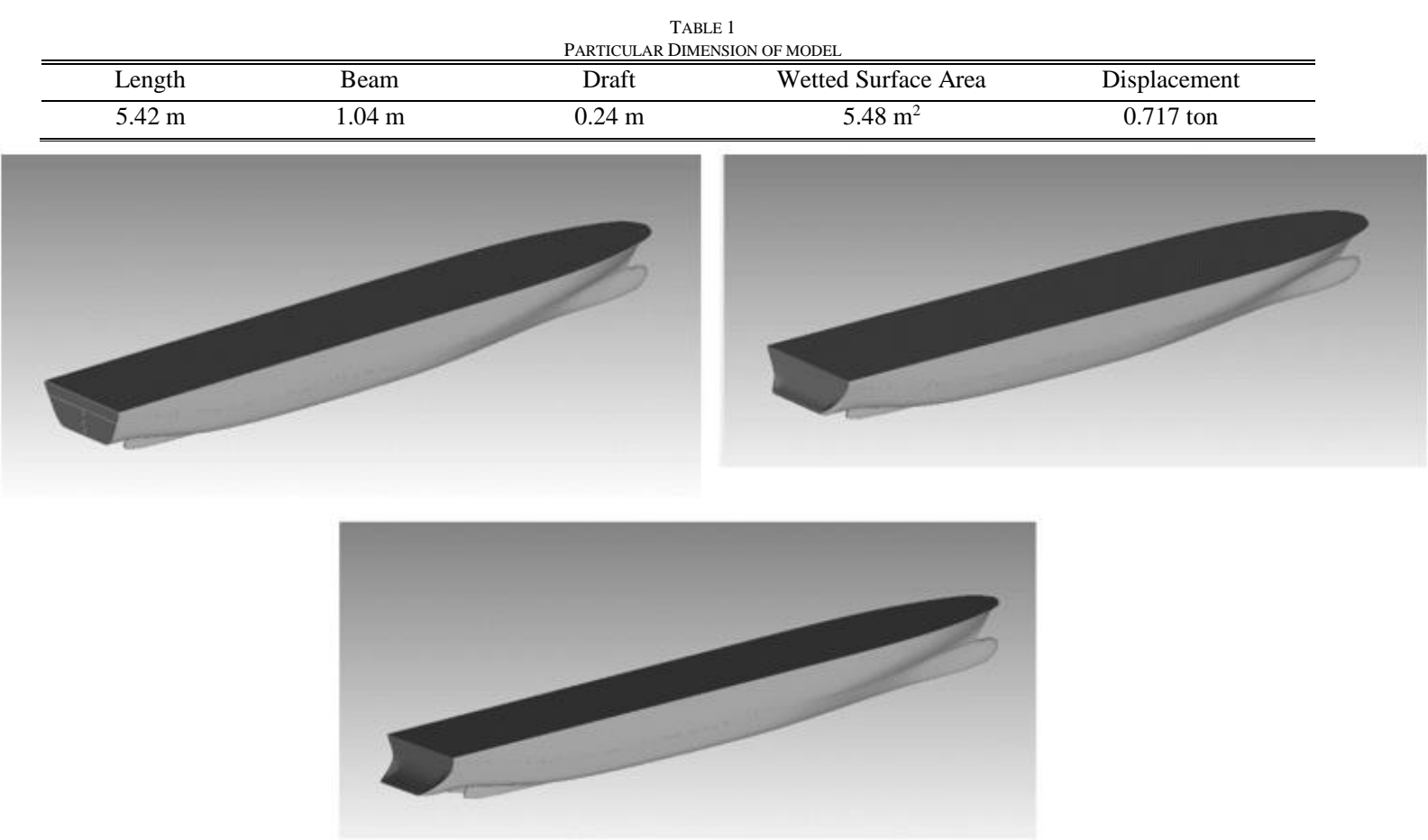

Figure.1. (a) Model ferry initial. (b) Model ferry with ducktail 3 meter. (c) Model ferry with ducktail 6 meter

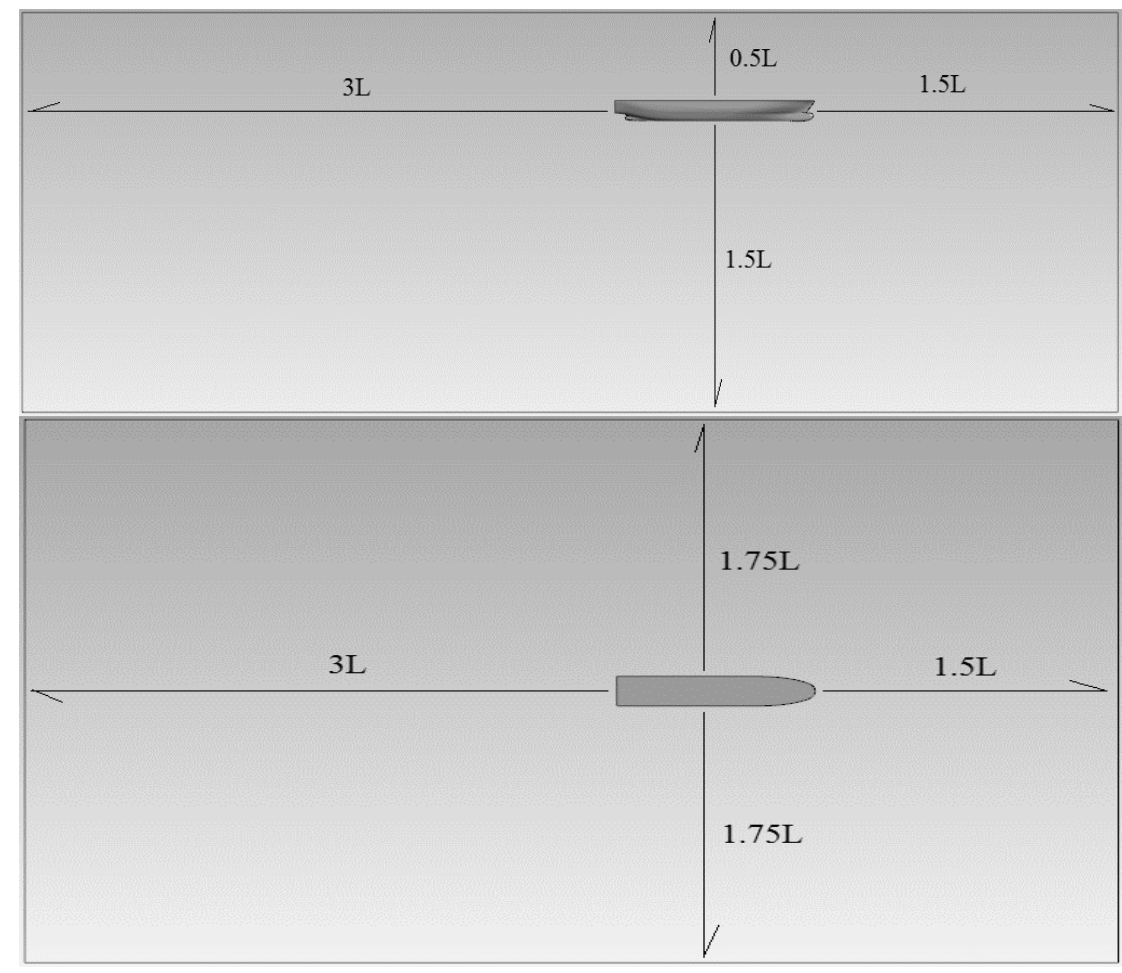

Figure 2. Computational Domain

The pressure and velocity were correspondingly interpolated using linear and trilinear numerical schemes. Finally, root mean square (RMS) criterion with a residual target value of $1 \times 10-5$ was used to check the convergence of the solutions.

\section{RESULTS AND DISCUSSION}

The number and distribution of GCPs will affect the accuracy of orthorectified imagery. In this case, we used 15 GCPs and its distribution evenly across the whole area (Figure 1). All GCPs is tied attached to a temporary base station in Bontang which tied by CORS base station in
Balikpapan (CBAL). The distance between the temporary base station and CBAL is approximately $230 \mathrm{~km}$ and observed for 10 hours. Then, all GCPs point is tied to the temporary base station and measured by radial method and 1 hour observation. The all GCPs have a horizontal accuracy of less than $20 \mathrm{~cm}$ in accordance with the required by BIG [7] [8]. We used GNSS receiver (Sokkia GRX1) to determine coordinate GCPs with radial method and 1 hour observation. The results of GNNS is less than $2 \mathrm{~cm}$. It means the result is very high accuracy because the requirement only less than $20 \mathrm{~cm}$. 


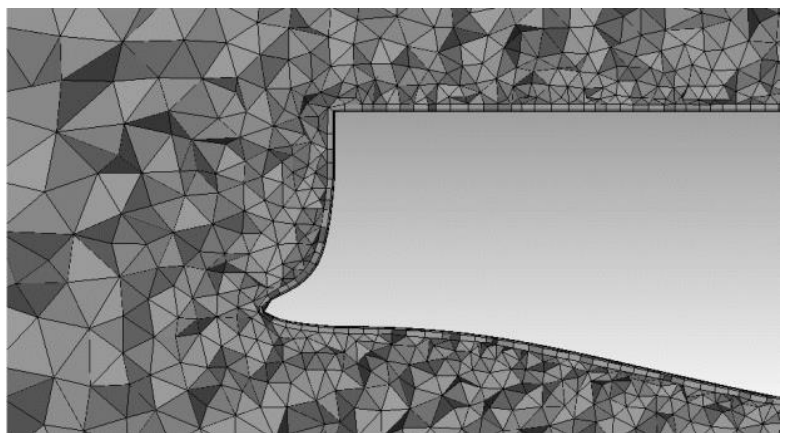

Figure 3. Hybrid Mesh of unstructured tetrahedral and inflation layer
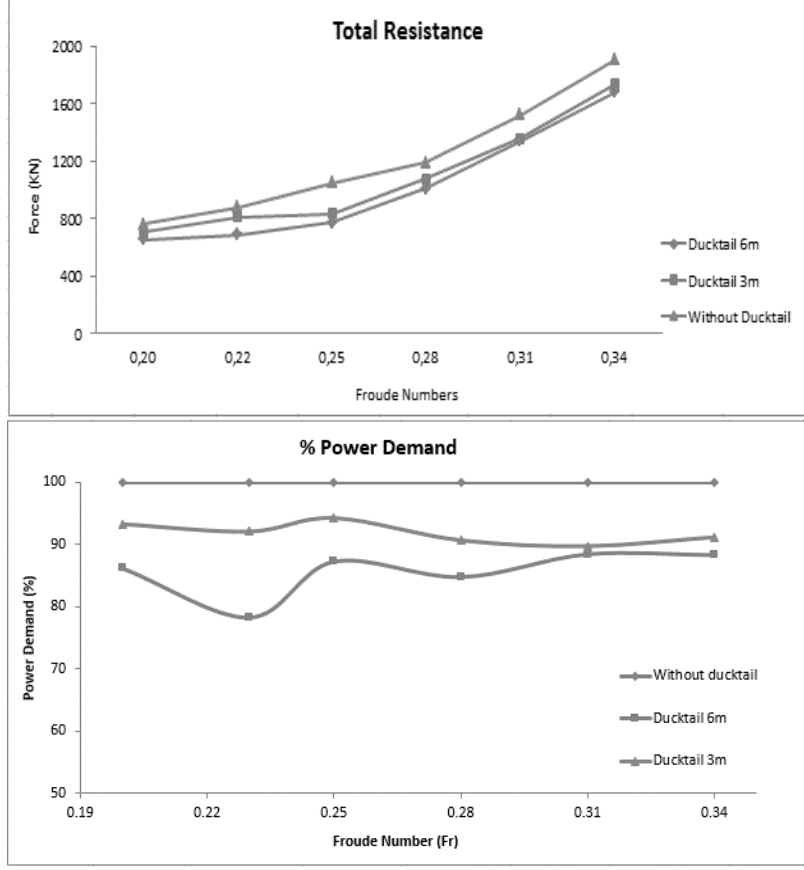

Figure 4. Total Resistance and Power demand ship with ducktail and without ducktail

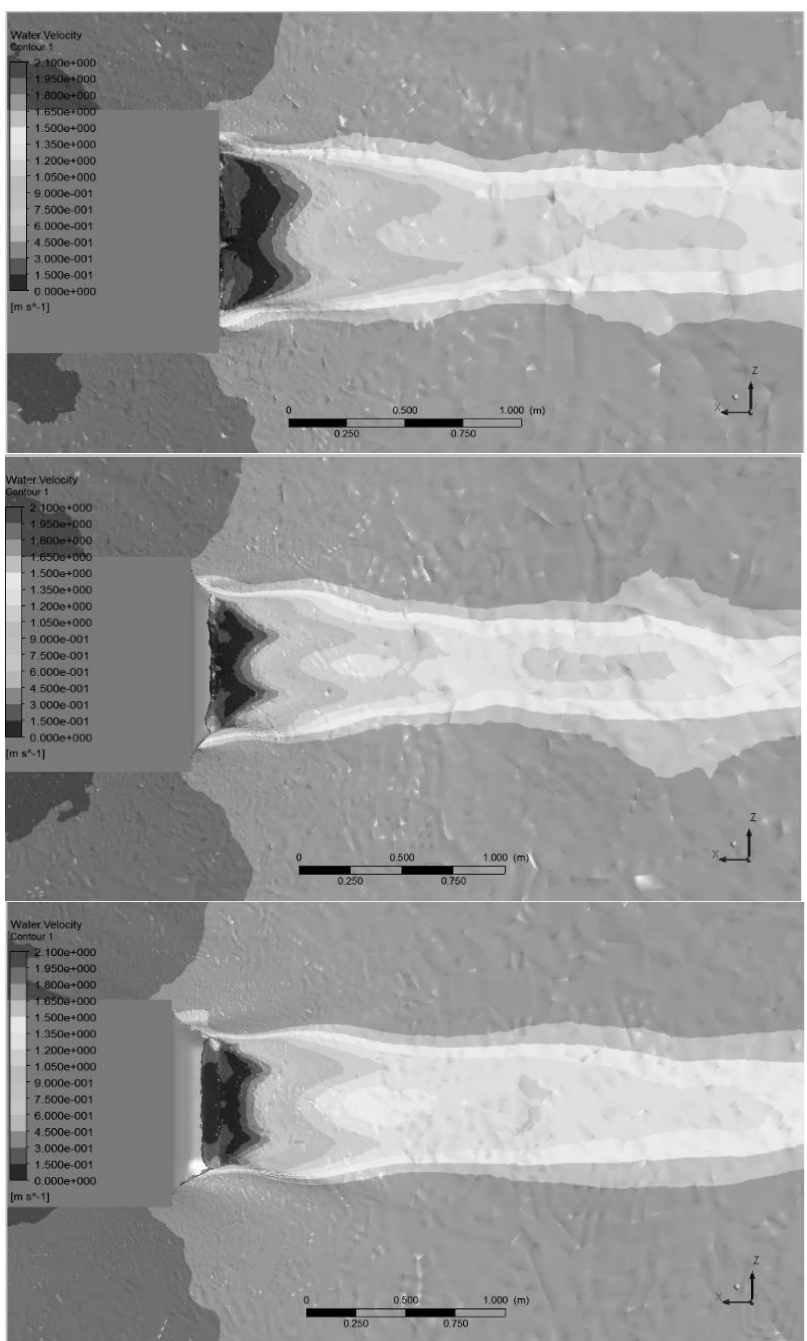

Figure 5. Velocity Contour (a) Ship Model without Ducktail; (b) Ship Model with Ducktail 3m; (c) Ship Model with Ducktail 6m

TABLE 3

COMPONENT COEFFICIENT RESISTANCE

\begin{tabular}{|c|c|c|c|c|c|c|c|c|c|}
\hline \multirow[b]{2}{*}{$\begin{array}{l}\text { Froude } \\
\text { numbers }\end{array}$} & \multicolumn{3}{|c|}{ Without Ducktail } & \multicolumn{3}{|c|}{ Ducktail $3 \mathrm{~m}$} & \multicolumn{3}{|c|}{ Ducktail 6} \\
\hline & $\begin{array}{c}\mathrm{C}_{\mathrm{T}} \\
\left(1 \times 10^{-3}\right)\end{array}$ & $\begin{array}{c}\mathrm{C}_{\mathrm{P}} \\
\left(1 \times 10^{-3}\right)\end{array}$ & $\begin{array}{c}\mathrm{C}_{\mathrm{F}} \\
\left(1 \times 10^{-3}\right)\end{array}$ & $\begin{array}{c}\mathrm{C}_{\mathrm{T}} \\
\left(1 \times 10^{-3}\right)\end{array}$ & $\begin{array}{c}\mathrm{C}_{\mathrm{P}} \\
\left(1 \times 10^{-3}\right)\end{array}$ & $\begin{array}{c}\mathrm{C}_{\mathrm{F}} \\
\left(1 \times 10^{-3}\right)\end{array}$ & $\begin{array}{c}\mathrm{C}_{\mathrm{T}} \\
\left(1 \times 10^{-3}\right)\end{array}$ & $\begin{array}{c}\mathrm{C}_{\mathrm{P}} \\
\left(1 \times 10^{-3}\right)\end{array}$ & $\begin{array}{c}\mathrm{C}_{\mathrm{F}} \\
\left(1 \times 10^{-3}\right)\end{array}$ \\
\hline 0,20 & 8,336 & 6,009 & 1,519 & 7,528 & 6,009 & 1,519 & 6,723 & 5,203 & 1,519 \\
\hline 0,22 & 7,396 & 5,096 & 1,495 & 6,591 & 5,096 & 1,495 & 5,413 & 3,918 & 1,495 \\
\hline 0,25 & 6,949 & 3,902 & 1,473 & 5,376 & 3,902 & 1,473 & 4,799 & 3,325 & 1,473 \\
\hline 0,28 & 6,405 & 4,160 & 1,455 & 5,615 & 4,160 & 1,455 & 5,074 & 3,619 & 1,455 \\
\hline 0,31 & 6,750 & 4,417 & 1,438 & 5,855 & 4,417 & 1,438 & 5,583 & 4,145 & 1,438 \\
\hline 0,34 & 7,108 & 4,846 & 1,423 & 6,269 & 4,846 & 1,423 & 6,047 & 4,624 & 1,423 \\
\hline
\end{tabular}

All GCPs and TerraSar-X DEM are used to orthorectification process of WorldView-2 images using Rational Polynomial Coefficients (RPC) method. The results showed that the accuracy of WorldView-2 orthorectified is 1.18 pixel. This means that the accuracy is smaller than 2.2 pixel which required by BIG [9].

Orthorectified WorldView-2 imagery was controlled by 22 ICPs which are distributed in the whole area (Figure 3 ). Horizontal accuracy is obtained by comparing the difference between the coordinates of the same object ICPs and orthorectified WorldView-2 imagery. In this case, we used 22 ICPs and the root mean square error (rmse) of orthorectified WorldView-2 is $1.32 \mathrm{~m}$ and the horizontal accuracy with circular error 90\% (CE90) is
$2.01(1.52 \times 1.32 \mathrm{rmse})$. This value is smaller than accuracy required by BIG (maximum $2.5 \mathrm{~m}$ ) [9].

\section{REFERENCES}

[1] Undang-Undang., 2011. "Undang-Undang Republik Indonesia No. 4 Tahun 2011 tentang Informasi Geospasial,”. Lembaran Negara Republik Indonesia Tahun 2011 Nomor 49. Jakarta

[2] Instruksi Presiden., 2012. "Instruksi Presiden RI No. 6 Tahun 2012 tentang Penyediaan, Penggunaan, Pengendalian Kualitas, Pengolahan dan Distribusi Data Satelit Penginderaan Jauh Resolusi Tinggi,”. Jakarta. 8 Mei 2012.

[3] Mercer, JB., Allan, J., Glass, N., Rasmussen, J., Wollersheim, M., "Orthorectification of Satellite Images Using External DEMS From IFSAR,”. Intermap Technologies Corp. \#1000, 736 - 8th Ave. S.W.,, Calgary Canada. 
August $2^{\text {nd }} 2016$, Postgraduate Program Institut Teknologi Sepuluh Nopember, Surabaya, Indonesia

[4] Boccardo, P., Mondino, E.B., Tonolo, F.G., Lingua, A., "Orthorectification of High Resolution Satellite Images,". Politecnico di Torino, Dipartimento di Georisorse e Territorio, Torino - Italy

[5] Yamane, N., Fujita, K., Nonaka, T., Shibayama, T., Takagishi, S., "Accuracy Evaluation of DEM Derived By TerraSar-X Data in The Himalayan Region" The International Archives of the Photogrammetry, Remote Sensing and Spatial Information Sciences. Vol. XXXVII. Part B7. Beijing 2008

[6] Badan Informasi Geospasial, 2015., "Modul Validasi Peta Rencana Tata Ruang. Modul 1 Sumber Data,”. Bogor
[7] Badan Informasi Geospasial, 2015.,"Modul Validasi Peta Rencana Tata Ruang. Modul 2 Sebaran Dan Pemilihan Titik,". Bogor

[8] Badan Informasi Geospasial, 2015., "Modul Validasi Peta Rencana Tata Ruang. Modul 3 Pengukuran GPS,". Bogor

[9] BIG, 2015. "Modul Validasi Peta Rencana Tata Ruang. Modul 4 Orhorektifikasi dan Uji Akurasi,". Bogor 